\title{
Langerhans cell histiocytosis
}

\author{
INSERM
}

\section{Source}

INSERM. (1999). Orphanet: an online rare disease and orphan drug data base.

Langerhans cell histiocytosis. ORPHA:389

Langerhans cell histiocytosis ( $\mathrm{LCH}$ ) is a systemic disease associated with the proliferation and accumulation (usually in granulomas) of Langerhans cells in various tissues. 